\title{
DNA-dependent RNA synthesis in isolated nuclei from Saccharomyces carlsbergensis
}

A DNA-dependent synthesis of RNA has been proved to occur in the nuclei of a number of mammalian and plant tissues (e.g. refs. I-3). Moreover, the presence of enzymes catalyzing RNA synthesis under the direction of DNA has been established in various microorganisms (e.g. refs. 4-6) and substantial purification of one of these enzymes has been reported?

As a result of our studies on protein synthesis in protoplasts of Saccharomyces carlsbergensis ${ }^{8,9}$ we became interested in the nuclear synthesis of RNA. Therefore, we have studied the RNA synthesizing activity of nuclei isolated from the same protoplasts according to the method of ROZIJN and ToNINO ${ }^{10}$. In this paper, preliminary results are presented, indicating the occurrence of DNA-dependent RNAsynthesis in our preparations of isolated nuclei.

The nuclei were isolated from $S$. carlsbergensis cells in a medium containing $0.02 \mathrm{M}$ potassium phosphate ( $\mathrm{pH} 6.5$ ), $0.0005 \mathrm{M} \mathrm{MgCl}_{2}$ and $8 \%$ polyvinylpyrrolidone ("PVP medium").

The following procedure was used: S. carlsbergensis cells were converted to protoplasts as described previously ${ }^{11}$. The protoplasts were lysed in PVP medium containing $0.02 \%$ Triton X-I0o. The lysate was homogenized in a Potter-Elvehjem type homogenizer and diluted immediately with an equal volume of a $0.6 \mathrm{M}$ solution of sucrose in PVP medium. The resulting homogenate was centrifuged at $3000 \times g$ for $7 \mathrm{~min}$ to sediment the nuclei. The crude nuclear sediment thus obtained was purified either by washing twice with $0.6 \mathrm{M}$ sucrose-PVP medium (preparation A), or by high-speed centrifugation on a layered gradient of I.2-2.0 M sucrose in PVP medium (preparation B). Preparation A was still contaminated with small amounts of membraneous material, whereas the contamination in preparation $B$ was negligible. Full details of the isolation procedure will be published elsewhere ${ }^{10}$.

As it was easier to obtain preparation $A$ in substantial amounts than preparation $B$, we used preparations $A$ for the routine determination of DNA-dependent RNA synthesis as well as for studying the sucrose gradient ultracentrifuge patterns of newly synthesized RNA. However, from the data in Table I it can be seen that pure preparations of nuclei - although less active - also show RNA-synthesizing ability. Routinely, the complete incubation medium in which RNA synthesis was studied contained $40 \mathrm{mg}$ polyvinylpyrrolidone, $200 \mathrm{mg}$ sucrose, $50 \mathrm{mg}$ glucose, $20 \mu$ moles $\mathrm{MgCl}_{2}$, ro $\mu$ moles phosphate buffer ( $\mathrm{pH} 6.8$ ), $2 \mu$ moles UTP, $2 \mu$ moles CTP, $2 \mu$ moles GTP, $0.8 \mu$ mole $\left[{ }^{14} \mathrm{C}\right]$ ATP $\left(3 \cdot 10^{5}\right.$ counts $\left./ \mathrm{min}\right)$ and $3-5 \mathrm{mg}$ nuclear protein per $\mathrm{ml}$.

After 30 or $60 \mathrm{~min}$ of incubation at $30^{\circ}$, a solution was added which contained, for each $\mathrm{ml}$ of medium, $6 \mathrm{mg}$ of carrier $\mathrm{RNA}$, o.I $\mathrm{ml}$ of Io \% sodium laurylsulphate and $0.05 \mathrm{ml}$ of I M NaCl. This was followed by phenol extraction of the RNA according to $\mathrm{KIRBY}^{12}$. After I5 min centrifugation at $3000 \times \mathrm{g}$, the water layer was separated from the phenol layer. The nucleic acid was precipitated from the water layer by the addition of cold Io \% trichloroacetic acid. As it proved to be rather difficult to wash out all $\left[{ }^{14} \mathrm{C}\right] \mathrm{ATP}$, Io $\mathrm{mg}\left[{ }^{12} \mathrm{C}\right] \mathrm{ATP}$ was added to the water layer 
before the precipitation of RNA with trichloroacetic acid. Subsequently, the RNA precipitate was washed as described before ${ }^{13}$, dissolved in formic acid, plated, and counted in a Philips electronic counter type P.W. 4032 after evaporation of the formic acid. Data of illustrative experiments with preparations $\mathrm{A}$ and $\mathrm{B}$ respectively are presented in Table I.

TABLE I

SYNTHESIS OF RNA FROM S. carlsbergensis

RNA synthesis at $30^{\circ}$ by isolated nuclei from S. carlsbergensis, determined as the incorporation of ${ }^{14} \mathrm{C}$ label from $\left[{ }^{14} \mathrm{C}\right] \mathrm{ATP}$. Complete system as described in the text; the time of incubation was $60 \mathrm{~min}$.

\begin{tabular}{ccc}
\hline $\begin{array}{c}\text { Preparation } \\
\text { of nuclei }\end{array}$ & \multicolumn{1}{c}{ Remarks } & $\begin{array}{c}\text { Radioactivity of } \\
\text { RNA precipitate } \\
\text { (counts/min/mg) }\end{array}$ \\
\hline A & Complete system & 94 \\
A & $\begin{array}{c}\text { Nuclei preincubated Io min } \\
\text { with Io } \mu \text { g DNAase/ml }\end{array}$ & 32 \\
A & $\begin{array}{c}\text { Nuclei preincubated 1o min } \\
\text { with Io } \mu \text { g actinomycin D/ml }\end{array}$ & 45 \\
A & RNA-extract treated with Io $\mu \mathrm{g}$ & 16 \\
A & RNAase*/ml & \\
A & No UTP & 46 \\
A & No CTP & 66 \\
B & No GTP & 55 \\
\hline
\end{tabular}

* EC 2.7.7.16.

From the results shown in Table I, it can be concluded that isolated nuclei from S. carlsbergensis show a DNAase (EC 3.I.4.5) and actinomycin D-sensitive RNA synthesis. For an optimal activity of the system all four ribonucleoside triphosphates are needed.

As we were interested in knowing something about the size of the RNA being synthesized in the nuclear preparations, we studied ultracentrifuge patterns of the labeled RNA preparations in a $20-5 \%$ sucrose gradient. Again, the RNA was extracted with phenol from an incubation medium to which RNA was added as described above, precipitated at $\mathrm{pH} 5$ from the water layer by the addition of a double volume of cold ethanol, redissolved in a small volume of versene- $\mathrm{NaCl}-\mathrm{Tris}$ buffer solution of concentrations, $0.00 \mathrm{r}, 0.02$ and $0.005 \mathrm{M}$, respectively, and carefully titrated to $\mathrm{pH} 7$. Subsequently, a $0.2 \mathrm{ml}$ sample was layered on a $5 \mathrm{ml} 20-5 \%$ sucrose gradient and spun for $5 \mathrm{~h}$ at 37 ooo revs./min in a SW 39 Spinco rotor. After puncture of the tube fractions were collected and their radioactivity was determined as described above, after the addition of another $6 \mathrm{mg}$ carrier RNA per sample. Fig. I shows the gradient patterns of ${ }^{14} \mathrm{C}$-labeled RNA as obtained after 30 and $60 \mathrm{~min}$ of incubation, respectively.

The gradient patterns shown in Fig. I strongly suggest that with increasing time of incubation a larger amount of RNA label moves to the heavier fractions of the 


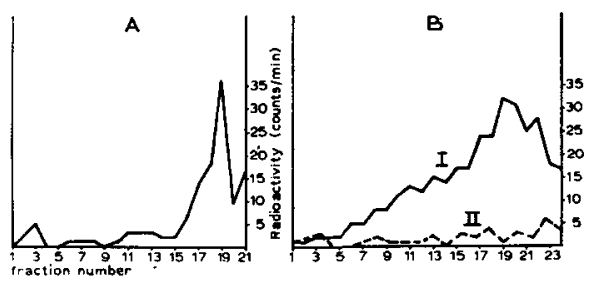

Fig. I. Sucrose gradient patterns of ${ }^{14} \mathrm{C}$-labeled RNA extracted after (A) 30 and (B) $60 \mathrm{~min}$ from an incubation medium as described in the text. Next to $3 \cdot 10^{5}$ counts $/ \mathrm{min}\left[{ }^{14} \mathrm{C}\right] \mathrm{ATP}$ per $\mathrm{ml}$, the medium used for experiment $B$ contained $3.10^{5}$ counts $/ \mathrm{min} / \mathrm{ml}\left[{ }^{14} \mathrm{C}\right] \mathrm{UTP}$. B I: Patteri of nuclear RNA; B II : Pattern of the same RNA, after a Io min treatment with ro $\mu$ gr/ml RNAase. Ultraviolet-light absorption patterns are left out as they have to be attributed mainly to the carrier RNA.

gradient. As it is known $\mathbf{1 4}^{\mathbf{1 4} 15}$ that after 5 h of $20-5 \%$ sucrose gradient centrifugation the RNA with a sedimentation coefficient of $23 \mathrm{~S}$ and a mol. weight of $1.2 \cdot 10^{6}$ moves to about fraction $\mathrm{I}_{3}$, this would mean that isolated nuclei of $S$. carlsbergensis are still able to synthesize or at least to finish the synthesis of macromolecular RNA.

This investigation was supported in part by U. S. Public Health Service Research Grant RF 50 and by the Netherlands Foundation for Chemical Research (S.O.N.) with financial aid from the Netherlands Organization for the Advancement of Pure Research (Z.W.O.).
Laboratory for Physiological Chemistry,
Th. H. RozIJN
State University,
G. J. M. Tonino
Utrecht (The Netherlands)
Van 't Hoff Laboratory,
State University,
E. M. B. Frens-v. D. Bilt
Utrecht (The Netherlands)
H. P. J. BLOEMERS
V. V. KONINGSBERGER

1 S. B. Weiss, Proc. Natl. Acad. Sci. U.S., 47 (1960) 1ozo.

2 V. G. Allfrey and A. E. Mirsky, Proc. Natl. Acad. Sci. U.S., $4^{8}$ (1962) I59o.

3 R. C. Huang, N. Makeshwari and J. Bonner, Biochem. Biophys. Res. Commun., 3 (I960) 689.

4 J. Hurwitz A. Bresler and R. Diringer, Biochem. Biophys. Res. Commun., 3 (Ig60) I5.

- A. Stevens, J. Biol. Chem, 236 (Ig6i) PC 43.

- S. B. Weiss and T. Nakomoto, J. Biol. Chem., 236 (I96I) PC I8.

7 J. Hurwitz, A. Evans, C. Bobinet and A. Skalka, 28th Cold Spring Harbor Symp. Quant. Biol., June I963.

8 V. V. Koningsberger, in R. J. C. Harris, Protein Biosynthesis, Academic Press, London and New York, I96I, p. 207.

- S. R. De Kloet, L. B. Barnett, H. P. J. Bloemers and V. V. Koningsberger, Proc. Koninkl. Ned. Akad. Wetenschap., Ser. B, 66 (1963) 332.

10 Th. H. Rozijn and G. J. M. Tonino, in preparation.

11 G. J. M. Tonino and E. P. Steyn Parvé, Biochim. Biophys. Acta, 67 (1963) 453.

12 K. S. KIRBY, Biochem. J., 64 (I950) 405.

13 L. B. Barnett, G. Frens and V. V. Koningsberger, Proc. Koninkl. Ned. Akad. Wetenschap., Ser. B, $59(\mathbf{I} 962) 4 \mathrm{I} 8$.

14 C. G. Kurland, J. Mol. Biol., 2 (1960) 83.

is H. P. J. Bloemers and V. V. Koningsberger, unpublished.

Received March 4th, I964 